\title{
FORMULATION AND DETAILED CHARACTERIZATION OF VORICONAZOLE LOADED IN SITU GELS FOR OCULAR APPLICATION
}

\author{
OKÜLER UYGULAMA ICCINN VORIKONAZOL YÜKL Ü IN SITU JELLERIN \\ FORMÜLASYONU VE DETAYLI KARAKTERIZASYONU
}

\section{Neslihan USTUNDAG OKUR ${ }^{1 *}$, Vildan YOZGATLI ${ }^{2}$, Zeynep SENYIGIT ${ }^{3}$}

${ }^{1}$ University of Health Sciences, Faculty of Pharmacy, Department of Pharmaceutical Technology,

\author{
Istanbul, TURKEY
}

${ }^{2}$ Ege University, Faculty of Pharmacy, Department of Pharmaceutical Technology, Bornova, Izmir,

\section{TURKEY}

${ }^{3}$ İzmir Kâtip Çelebi University, Faculty of Pharmacy, Department of Pharmaceutical Technology, Izmir, TURKEY

\section{ABSTRACT}

Objective: This study was aimed to prepare, characterize and evaluate in situ gel formulation for a sustained ocular delivery of voriconazole.

Material and Method: In situ gels were prepared with three different hydrophilic co-polymers: Poloxamer 188, 407 and 388. The formulations were characterized in terms of their clarity, $p H$, viscosity drug content uniformity and mechanical/rheological properties. Moreover, in vitro drug release and stabilitystudies were performed.

Result and Discussion: The results showed that the optimized in situ gel formulation had desired in vitro properties and a good stability over the period of 3 months. Texture profile analysis presented that formulations offered suitable adhesive and mechanical properties. P2-V formulation exhibited pseudoplastic flow and typical gel-type mechanical spectra $\left(G^{\prime}>G^{\prime \prime}\right)$ at different frequecy values and at different temperatures. Moreover, all formulations showed a sustained drug release for 24 hours. In conclusion, voriconazole loaded in situ gel could be offered as an encouraging strategy as ocular systems for ocular infections treatment.

Keywords: Mechanical properties poloxamer, rheological properties, thermo-sensitive in situ gel, voriconazole

\footnotetext{
* Sorumlu Yazar / Corresponding Author: Neslihan Üstündağ Okur e-mail/e-posta: neslihanustundag@yahoo.com
} 


\section{ÖZ}

Amaç: Bu çalışmada vorikonazolün sürekli bir oküler dağılım uygulaması için in situ jel formülasyonu hazırlamak, karakterize etmek ve değerlendirmek amaçlanmıştır.

Gereç ve Yöntem: In situ jeller, üç farklı hidrofilik yardımcı polimer ile hazırlanmıştır: Poloxamer 188, 407 ve 388. Formülasyonlar, berraklık, pH, viskozite ilaç içeriği ve mekanik / reolojik özellikleri bakımından karakterize edilmiştir. Ayrıca, in vitro ilaç salımı ve stabilite çalışmaları yapılmıştır.

Sonuç ve Tartışma: Sonuçlar, optimize edilmiş in situ jel formülasyonunun, istenen in vitro özellikler ve 3 ay boyunca iyi bir stabilite göstermiştir. Doku profili analizi, formülasyonların uygun adhezif ve mekanik özellikler sunduğunu göstermiştir. P2-V formülasyonu, farklı frekans değerlerinde ve farklı sicaklıklarda psödo plastik akışl ve tipik jel tipi mekanik spektrumları $\left(G^{\prime}>G^{\prime \prime}\right)$ göstermiştir. Ayrıca, tüm formülasyonlar 24 saat boyunca sürekli bir ilaç salımı göstermiştir. Sonuç olarak, vorikonazol yüklü in situ jel, oküler enfeksiyon tedavisi için oküler sistemler olarak teşvik edici bir strateji olarak sunulabilir.

Anahtar Kelimeler: mekanik özellikler poloksamer, reolojik özellikler, termo-duyarlı in situ jel, vorikonazol

\section{INTRODUCTION}

Ocular drug delivery is challenging due to the presence of anatomical and physiological barriers. These barriers can affect drug entry into the eye following multiple routes of administration (e.g., topical, systemic, and injectable) [1]. Topical administration is the most common route of ocular drug delivery. This route represents a safer administration, therefore a major challenge to the scientists is to overcome the ocular barriers and reach the tissue target [2].

Although conventional opthalmic dosage forms such as solutions and suspensions are usually preferred to treat disorders of the eye, the biological protecting factors lead to low ocular absorption and poor bioavailability (1-10\%). An efficient ocular drug delivery system, which can provide maximum precorneal residence time, is desirable to overcome ocular barriers and sustain delivery of drugs following topical administration [3].

Bacterial keratitis may arise secondary to corneal epithelial breakdown associated with dry eye, contact lens use, trauma or the presence of a persistent corneal suture. Keratitis is also caused by direct infection or immune-related complications with viruses, bacteria, fungi, yeast and amoeba. Subsequent long term visual loss occurs as a consequence of corneal scarring affecting the visual axis. The extent of scarring may be limited if the infection is identified early and treated adequately [4,5]

A second-generation antifungal agent, voriconazole (VCZ), has exceptional properties such as broad-spectrum activity against resistant fungal species and acceptable tolerability. Besides, studies have demonstrated excellent efficacy of VCZ against ocular mucosa following topical administration $[6,7]$.

The in situ thermo-gelling systems are liquid aqueous solutions at room temperature, however they undergo sol-gel transition on the ocular surface at physiological temperature hence they prolong ocular residence time. Various in situ gel systems have been developed to prolong the precorneal duration of the drug and to increase ocular bioavailability [8,9]. Among commonly used in situ gel 
polymers, Poloxamers are well-known thermo-responsive copolymers that exist liquid state at low temperature $\left(4-5^{\circ} \mathrm{C}\right)$ while converting into a gel upon increasing temperature. They have been widely used in nasal, ophthalmic, vaginal and topical formulations. However, they represent weak mechanical strength leading to rapid erosion of the polymer.

Therefore; in this study, it was aimed to develop VCZ loaded in situ gel formulation with suitable gelation temperature and mechanical properties for ocular drug delivery. In accordance with this purpose, the in situ gels were prepared by using different poloxamer types (Poloxamer 188, 407, 388) and ratios. Finally, the gels were characterized in terms of their physicochemical parameters, drug content, mechanical/rheological properties, in vitro drug release and stability.

\section{MATERIAL AND METHOD}

\section{Materials}

VCZ was purchased from Sigma-Aldrich, Germany. Poloxamer 407, 188 and 338 were kindly gifted from BASF, Turkey. Benzalkonium chloride (BZC) was supplied from Sigma-Aldrich, Germany. Dialysis membrane (Spectra/por 4, diameter $16 \mathrm{~mm}$, the molecular weight of 12-14 kDa) was purchased from Spectrum Chemical Mfg. Corp. (USA). Distilled water was used throughout the study. All the other solvents and chemicals were of analytical or HPLC grade.

\section{Preparation of in situ gel formulations}

The in situ gels were prepared according to cold technique [10,11]. The polymeric solutions were prepared by dispersing the required quantity of Poloxamer 407 and Poloxamer 188 in water using a magnetic stirrer until the poloxamers completely dissolve. Aqueous solutions were stirred for about two hours by using magnetic stirrer [12].

For the preparation of ocular in situ gel; VCZ, BZC as well as sodium chloride were incorporated in aqueous solutions containing P407, P188, P388 and distilled water. BZC $(0.02 \% \mathrm{w} / \mathrm{w})$ was added as a preservative to the solutions. Sufficient amount of sodium chloride $(0.9 \% \mathrm{w} / \mathrm{w})$ was added to the mixture to maintain the isotonicity.

\section{Characterization of in situ gels}

\section{Appearance}

The developed formulations were inspected visually for their clarity, colour and particle content both in their sol state and gel state.

\section{Determination of sol-gel temperature ( $\left.\mathbf{T}_{\text {sol-gel }}\right)$}

$20 \mathrm{~g}$ of cold formulation was put into a beaker and placed in a temperature-controlled magnetic stirrer. A thermometer (JG-220 Digital Thermometer, Turkey, $-50+260^{\circ} \mathrm{C} \pm^{\circ} 1 \mathrm{C}$ accuracy) was 
immersed in the sample solution for constant monitoring. The solution was heated at the rate of $2^{\circ} \mathrm{C} / \mathrm{min}$ with the continuous with stirring at $200 \mathrm{rpm}$. The temperature at which the magnetic bar stopped moving due to gelation was reported as the gelation temperature. The maximum limit for gelation was checked up to $60^{\circ} \mathrm{C}$ and the study was repeated at least 3 times [9].

\section{Gelling capacity}

The gelling capacity of the prepared formulation was determined by placing a drop of the formulation in a beaker at $32 \pm 0.5^{\circ} \mathrm{C}$ and it was visually observed for gelling time [12].

\section{Determination of $\mathrm{pH}$}

The $\mathrm{pH}$ of the gel was measured using calibrated $\mathrm{pH}$ meter (Mettler Toledo, Switzerland). $\mathrm{pH}$ measurement was repeated at least 3 times and the average $\mathrm{pH}$ values of the formulations were calculated.

\section{Viscosity}

The viscosity studies of in situ gels was carried out using a Brookfield viscometer (LVDV-E, USA). The in situ gel formulations were analyzed with probe 27 at $200 \mathrm{rpm}$ and probe 07 at $20 \mathrm{rpm}$. Temperature was set to $+4 \pm 0.5^{\circ} \mathrm{C}$ and $25 \pm 0.5^{\circ} \mathrm{C}$ by a circulating bath.

\section{Drug content uniformity}

$0.125 \mathrm{~g}$ of the developed formulations was dissolved in $25 \mathrm{~mL}$ mobile phase and drug concentration was analyzed by high-performance liquid chromatography (HPLC).

\section{HLPC analysis}

The VCZ amount was determined with a HPLC system consisted of a gradient pump, a UV detector (Agilent 1100, Thermo Scientific, Germany) and C18 column $(5 \mu \mathrm{m}, 150 \times 4.6 \mathrm{~mm})$. The samples were analyzed at $256 \mathrm{~nm}$ with $1 \mathrm{~mL} / \mathrm{min}$ flow rate at $25^{\circ} \mathrm{C}$. The mobile phase was a mixture of acetonitrile: ultrapure water (50:50). The retention time of VCZ was $4.098 \mathrm{~min}$ [7]. The method was validated for linearity, limit of detection (LOD) and limit of quantitation (LOQ), precision, accuracy and specificity, selectivity and stability. The linearity between peak area and concentration was analyzed using calibration curve obtained from standard solutions of VCZ $(1-30 \mu \mathrm{g} / \mathrm{mL})$. The accuracy of an analytical method is the closeness of test results obtained by the method to the true value and is defined recovery. The prepared standard solutions were injected five times at different levels as a test sample. 8 $\mu \mathrm{g} / \mathrm{mL}$ solution was injected ten times in order to evaluate method precision, standard deviation (SD) and coefficient of variation. 


\section{Spreadability of VCZ loaded in situ gels}

To determine spreadability of VCZ loaded in situ gels, $0.1 \mathrm{~g}$ of VCZ loaded in situ gels were transferred to the center of a glass plate $(10 \mathrm{~cm} \times 10 \mathrm{~cm})$, which this glass plate had temperature $32 \pm$ $0.5^{\circ} \mathrm{C}$ and was compressed under another glass plate of the same size. Thus, the gel was spread out in between the plates. After one minute, the weight was removed and the diameter of the spread area $(\mathrm{cm})$ was measured. The measurement was performed in triplicate [9].

\section{Determination of Mechanical Properties}

Mechanical properties of gels were determined using a software-controlled penetrometer (TAXT Plus Texture Analyser Stable Micro Systems, UK) equipped with a $0.5 \mathrm{~kg}$ load cell. An analytical probe (10 mm diameter) was twice compressed into gels to a defined depth $(15 \mathrm{~mm})$ with a constant rate (test speed: $2 \mathrm{~mm} / \mathrm{s}$ ) at both 25 and $32^{\circ} \mathrm{C}$. Mechanical parameters (hardness, adhesiveness, compressibility, cohesiveness and elasticity) were calculated from the obtained force-time curves. Experiments were carried out at least six times [13].

\section{Rheological Measurements}

The rheological analysis of the formulations was performed with a controlled stress/controlled rate rheometer (TA Instruments, Discovery HR-1, Hybrid Rheometer, UK) both at $25^{\circ} \mathrm{C} \pm 0.1^{\circ} \mathrm{C}$ and $32^{\circ} \mathrm{C} \pm 0.1^{\circ} \mathrm{C}$.

Continuous shear analysis was performed in flow mode, in conjunction with parallel steel plate geometry (40 mm diameter) and gap of $1000 \mu \mathrm{m}$. Briefly, formulation sample was carefully applied to the lower plate of instrument, ensuring that formulation shearing was minimized and allowed to equilibrate for at least $1 \mathrm{~min}$ prior to analysis. Upward and downward flow curves were measured over a range of shear rates $(0-1000 \mathrm{~s}-1)$.

Oscillatory analysis was performed after determination of its linear viscoelastic region at $25^{\circ} \mathrm{C}$ and $32^{\circ} \mathrm{C}$, where stress was directly proportional to strain and the storage modulus remained constant. Frequency sweep analysis was performed over the frequency range of $0.1-10 \mathrm{~Hz}$ following application of a constant stress and standard gap size was $1000 \mu \mathrm{m}$.

Storage modulus $\left(\mathrm{G}^{\prime}\right)$ and loss modulus $\left(\mathrm{G}^{\prime \prime}\right)$, the loss tangent $(\tan \delta)$ and the dynamic viscosity $\left(\eta^{\prime}\right)$ and were determined. All rheological properties were examined with at least three replicates [1416]

\section{In vitro drug release studies}

In vitro release studies were carried out in simulated tear fluid (composition: sodium chloride $0.68 \mathrm{~g}$, sodium bicarbonate $0.22 \mathrm{~g}$, calcium chloride dihydrate $0.008 \mathrm{~g}$, potassium chloride $0.14 \mathrm{~g}$, and 
distilled deionized water to $100 \mathrm{~mL}$ [17] to mimic ocular conditions. $5 \mathrm{~g}$ of formulations were put into dialysis membrane (Spectra/Por Regenerated Cellulose, Molecular weight cut off 12-14 kDa) and capped with closures. Dialysis membranes were placed into $200 \mathrm{~mL}$ simulated tear fluid and stirred at $50 \mathrm{rpm}\left(32 \pm 0.1^{\circ} \mathrm{C}\right) .1 \mathrm{~mL}$ of sample was withdrawn at a predetermined time intervals of $30 \mathrm{~min}$ to during $12 \mathrm{~h}$ and the same volume of fresh medium was replaced. The samples were analyzed with HPLC for determination of the drug content.

\section{Stability of VCZ loaded in situ gels}

In order to check physical stability, VCZ in situ gels were stored at $4 \pm 1{ }^{\circ} \mathrm{C}$ in the refrigerator and $25 \pm 1^{\circ} \mathrm{C}$ (relative humidity $60 \%$ ) for 3 months. After storage visual appearance, clarity, $\mathrm{pH}$, gelling capacity and VCZ content of in situ gels were investigated. The experiments were repeated three times [18].

\section{Statistical data analysis}

Statistical data analysis was performed using the Student's t-test with $\mathrm{P}<0.05$ as the minimal level of significance.

\section{RESULT AND DISCUSSION}

\section{Preparation of In Situ Gel Formulations}

Poloxamers represent a class of amphiphilic triblock copolymers comprising a hydrophobic propylene oxide (PPO) block and two hydrophilic ethylene oxide (PEO) blocks, which can undergo a reversible sol-to-gel transition upon heating, as a function of their PEO:PPO ratio. Poloxamer 407 and poloxamer 188 are the two most commonly used poloxamer types for thermosensitive in situ gelling systems an d they are approved by US Food and Drug Administration (FDA) [19]. Poloxamer 338 is a new nonionic surface-active agent. The block copolymer poloxamer 338 in aqueous media exhibits micellar structures which can convert into gel like structures based on their length, concentration and temperature [20].

The in situ VCZ gels were prepared according to cold technique. Briefly, VCZ, BZC as well as sodium chloride were incorporated in aqueous solutions containing P407, P188, P338 and distilled water. BZC $(0.02 \% \mathrm{w} / \mathrm{w})$ was added as a preservative to the solutions. Sufficient amount of sodium chloride $(0.9 \% \mathrm{w} / \mathrm{w})$ was added to the mixture to maintain the isotonicity. VCZ concentration was $0.1 \%$ $(\mathrm{w} / \mathrm{w})$ in all formulations (Table 1$)$.

Different Poloxamer 407, 188 and 338 combinations were tried and evaluated according to their physical appearance and gelation temperature properties. Topical drug administration is the simplest and easiest route for localized drug delivery [21]. Topical administration of antifungal agents could have 
an increased impact on the antifungal therapy, given that current formulations present lack of efficacy due to the rising antifungal drug resistance [22]. For topical ocular formulations, the carriers are desired to gel at $32^{\circ} \mathrm{C}$, which is the eye surface temperature [23]. Among the tried formulations, the poloxamer ratios given in Table 1 were identified as the most appropriate in situ gelling system for ocular administration. Therefore, they were chosen as in situ ocular carrier system candidates for VCZ and evaluated for their properties.

Table 1. Formulation codes (FC) and components of in situ gels

\begin{tabular}{ccccccc}
\hline FC & $\begin{array}{c}\text { Poloxamer } \\
\mathbf{4 0 7}(\mathbf{\%})\end{array}$ & $\begin{array}{c}\text { Poloxamer } \\
\mathbf{1 8 8}(\mathbf{\%})\end{array}$ & $\begin{array}{c}\text { Poloxamer } \\
\mathbf{3 3 8}(\mathbf{\%})\end{array}$ & $\begin{array}{c}\text { VCZ } \\
\mathbf{( \% )}\end{array}$ & $\begin{array}{c}\text { BZC } \\
\mathbf{( \% )}\end{array}$ & $\begin{array}{c}\text { Physiological saline (0.9\% } \\
\mathbf{w} / \mathbf{w})(\mathbf{q . s})(\mathbf{g})\end{array}$ \\
\hline P1-V & 20 & 5 & - & 0.1 & 0.02 & 100 \\
\hline P2-V & 20 & 8 & - & 0.1 & 0.02 & 100 \\
\hline P3-V & 20 & 18 & 0.5 & 0.1 & 0.02 & 100 \\
\hline
\end{tabular}

\section{Characterization of in situ gel formulations}

Psysicochemical parameters of in situ gel formulations are important factors to be considered in the formulation development phase especially for ocular application. Firstly, the formulations were inspected visually for organoleptic properties. Clarity is a quality control test to reduce number of the large particles in the formulation which may cause irritation and tear flow and hence the loss of drug from ocular surface [24]. Therefore; first of all, formulations were visually inspected for their clarity, color and particle content. Visual observation showed that all of the in situ gels were found to be clear, colorless and free of foreign particles.

In previous studies, the corneal contact time has been increased to varying degrees by different ophthalmic dosage forms. However, most of these carriers (e.g. ointments) have not been fully accepted, because of blurred vision [25]. In this respect; in situ gels are advantageous because of their transparent structure. In addition, they extend the corneal contact time and, in this way, they also increase patient compliance.

$\mathrm{pH}$ is one of the most important parameters involved in ophthalmic formulations and it was measured using a pre-calibrated $\mathrm{pH}$-meter. The normal physiological $\mathrm{pH}$ of the ocular mucosa ranges from 6.5 - 8.5 [9]. $\mathrm{pH}$ value of all formulations was found to be between $7.1-7.5$ and they are within the range of ocular mucosa (Table 2). 
Table 2. Physicochemical properties of $i n$ situ gels

\begin{tabular}{|c|c|c|c|c|c|c|c|}
\hline \multirow{2}{*}{ FC } & \multirow{2}{*}{ Clarity } & \multirow{2}{*}{ pH } & \multirow{2}{*}{$\begin{array}{l}\text { Gelling } \\
\text { temperature } \\
(0 \mathrm{C})\end{array}$} & \multirow{2}{*}{$\begin{array}{c}\text { Gelling } \\
\text { Capacity } \\
\text { (sec) }\end{array}$} & \multirow{2}{*}{$\begin{array}{l}\text { Spreadability } \\
\text { (cm) }\end{array}$} & \multicolumn{2}{|c|}{ Viscosity (cP) } \\
\hline & & & & & & $+4^{\circ} \mathrm{C}$ & $25^{\circ} \mathrm{C}$ \\
\hline P1 & +++ & $\begin{array}{c}7.375 \\
\pm 0.009\end{array}$ & $\begin{array}{l}30.733 \\
\pm 0.231\end{array}$ & $\begin{array}{l}2.100 \\
\pm 0.1\end{array}$ & $\begin{array}{c}1.575 \\
\pm 0.035\end{array}$ & $13.467 \pm 0.141^{*}$ & $255.00 \pm 1.838^{*}$ \\
\hline P1-V & +++ & $\begin{array}{c}6.327 \\
\pm 0.006 \\
\end{array}$ & $\begin{array}{l}30.500 \\
\pm 0.500 \\
\end{array}$ & $\begin{array}{c}1.800 \\
\pm 0.100 \\
\end{array}$ & $\begin{array}{c}1.300 \\
\pm 0.082 \\
\end{array}$ & $15.697 \pm 0.135^{*}$ & $275.10 \pm 2.796^{*}$ \\
\hline $\mathbf{P 2}$ & +++ & $\begin{array}{c}7.168 \\
\pm 0.009\end{array}$ & $\begin{array}{l}32.233 \\
\pm 0.115\end{array}$ & $\begin{array}{c}1.300 \\
\pm 0.100\end{array}$ & $\begin{array}{c}1.625 \\
\pm 0.035\end{array}$ & $110.000 \pm 3.270^{*}$ & $276.15 \pm 0.212 *$ \\
\hline P2-V & +++ & $\begin{array}{c}6.357 \\
\pm 0.006\end{array}$ & $\begin{array}{l}32.200 \\
\pm 0.265\end{array}$ & $\begin{array}{c}1.233 \\
\pm 0.058\end{array}$ & $\begin{array}{c}1.575 \\
\pm 0.096\end{array}$ & $125.50 \pm 4.270^{*}$ & $285.26 \pm 0.314 *$ \\
\hline $\mathbf{P 3}$ & +++ & $\begin{array}{c}7.553 \\
\pm 0.019 \\
\end{array}$ & $\begin{array}{l}27.300 \\
\pm 0.200 \\
\end{array}$ & $\begin{array}{c}1.800 \\
\pm 0.100 \\
\end{array}$ & $\begin{array}{c}1.487 \\
\pm 0.052 \\
\end{array}$ & $432.933 \pm 0.751^{*}$ & $550.00 \pm 4.142 * *$ \\
\hline P3-V & +++ & $\begin{array}{c}6.617 \\
\pm 0.006\end{array}$ & $\begin{array}{l}27.767 \\
\pm 0.306\end{array}$ & $\begin{array}{c}1.500 \\
\pm 0.100\end{array}$ & $\begin{array}{c}1.325 \\
\pm 0.096\end{array}$ & $445.266 \pm 0.642 *$ & $575.20 \pm 3.213 * *$ \\
\hline
\end{tabular}

(*: probe $27200 \mathrm{rpm} ; * *$ : probe $0720 \mathrm{rpm})$

An ideal in situ forming gel should be free flowing at a low temperature, transform into a semisolid after contacting the ocular surface, and remain in the gel form under conditions of maximum lacrimal fluid dilution [26]. The in situ gels developed in this study showed a gelation temperature around $32^{\circ} \mathrm{C}$. At this temperature, the administered formulations are expected to transform from sol to gel state and prolong the ocular drug release. It can also be seen from Table 2 that, incorporation of $\% 0.1$ VRC didn't significantly affect the gelling temperature and gelling capacity of the formulations.

The gelling capacity is defined as the time taken for the transition of liquid phase to a gel. In this experiment, the gelling capacities of in situ gels were found to be within $0.5-2.1 \mathrm{sec}$. As demonstrated in Table 2, the gelling capacity increased when the concentration of P188 increased. For example, formulation P1 has longer gelation time $(2.1 \mathrm{sec})$ than P2 formulation $(1.3 \mathrm{sec})$.

The results of viscosity were shown in Table 2 . The viscosity results of the formulations were different under 4 and $25{ }^{\circ} \mathrm{C}$ temperature conditions which are storage conditions of the in situ gel formulations. As the collected results showed, the increasing concentration of Poloxamer 188 increased the viscosity of the in situ gel. Poloxamer 188 is a more hydrophilic poloxamer and is used as an auxiliary gelling agent for modification of Tsol-gel. P188 consists of higher PEO: PPO ratio (79:28) compared to P407 (100:65) and usually incorporated in the P407 thermogels to increase the Tsol-gel [19].

The spreadability results showed that the formulated in situ gels (P2 and P2-V) were most effective i.e. they showed best results for spreadability. The results of spreadability were shown in Table 2. Spreading diameter of the P1, P1-V, P3 and P3-V formulations demonstrated that is similar for all formulations.

The analytical method was developed and validation studies were carried out for VRZ. If the standard deviation less than the acceptance criteria which is $2 \%$, the analysis system for the determination of assay is to verify [27]. The LOD and LOQ tests for the procedure were performed on 
samples containing very low concentrations of analyses [28]. The LOD and LOQ were determined as $0.022 \mu \mathrm{g} / \mathrm{mL}$ and $0.065 \mu \mathrm{g} / \mathrm{mL}$, respectively. The used method for VCZ analysis was found to be linear. Finally, the drug content uniformity of P1-V, P2-V and P3-V were found to be $93.622 \pm 1.157$, $92.625 \pm 0.609$ and $98.288 \pm 0.630$, respectively.

\section{Determination of Mechanical Properties}

Ocular in situ gel formulations should have suitable mechanical properties for easy administration, high spreadability on the ocular mucosa and strong adhesion. Texture profile analyses (TPA) were performed to gather information about the gel structure and to determine the resistance of formulations to compressive stresses and subsequent relaxation. The mechanical properties of the formulations were characterized in terms of hardness, compressibility, adhesiveness, elasticity and cohesiveness. The obtained results and force-time curves were given in Table 3, Figure 1 and Figure 2.

Briefly, hardness expresses the applicability of the gel to ocular surface and it should be low to allow easy administration and good spreadability. Compressibility value determines sample deformation under compression. It should be low to remove the formulation easily from the container during administration. This value also shows high spreadability at the application site. It can be seen that, depending on the increase in the temperature; hardness and compressibility values were significantly increased, which indicates, improved gel strength. This increase was in accordance with oscillatory rheology results, i.e. increased elastic behavior (represented by $G^{\prime}$ ) was exhibited with increasing temperature.

Table 3. Mechanical properties of the formulations

\begin{tabular}{|l|l|l|l|l|l|l|}
\hline $\begin{array}{l}\text { Formula } \\
\text { tion code }\end{array}$ & $\begin{array}{l}\text { Temperature } \\
\left({ }^{\circ} \mathbf{C}\right)\end{array}$ & $\begin{array}{l}\text { Hardness } \\
(\mathbf{g}) \pm \text { SD }\end{array}$ & $\begin{array}{l}\text { Compressibility } \\
(\mathbf{g} \cdot \mathbf{s e c}) \pm \text { SD }\end{array}$ & $\begin{array}{l}\text { Adhesiveness } \\
(\mathbf{g} \cdot \mathbf{s e c}) \pm \text { SD }\end{array}$ & $\begin{array}{l}\text { Cohesiveness } \\
\pm \text { SD }\end{array}$ & $\begin{array}{l}\text { Elasticity } \\
\pm \text { SD }\end{array}$ \\
\hline \multirow{2}{*}{ P1 } & $25^{\circ} \mathrm{C}$ & $0.588 \pm 0.025$ & $1.087 \pm 0.013$ & $0.594 \pm 0.017$ & $1.057 \pm 0.027$ & $0.968 \pm 0.010$ \\
\cline { 2 - 7 } & $32^{\circ} \mathrm{C}$ & $8.167 \pm 0.904$ & $12.852 \pm 2.395$ & $12.885 \pm 2.913$ & $1.033 \pm 0.083$ & $1.532 \pm 0.189$ \\
\hline \multirow{2}{*}{ P1-V } & $25^{\circ} \mathrm{C}$ & $0.603 \pm 0.015$ & $1.121 \pm 0.047$ & $0.608 \pm 0.020$ & $1.052 \pm 0.008$ & $1.018 \pm 0.061$ \\
\cline { 2 - 7 } & $32^{\circ} \mathrm{C}$ & $12.508 \pm 0.715$ & $19.939 \pm 2.914$ & $18.838 \pm 2.354$ & $1.016 \pm 0.031$ & $1.504 \pm 0.462$ \\
\hline \multirow{2}{*}{$\mathbf{P 2}$} & $25^{\circ} \mathrm{C}$ & $0.231 \pm 0.015$ & $0.161 \pm 0.017$ & $0.581 \pm 0.010$ & $0.976 \pm 0.025$ & $1.013 \pm 0.169$ \\
\cline { 2 - 7 } & $32^{\circ} \mathrm{C}$ & $10.255 \pm 2.261$ & $13.947 \pm 2.059$ & $11.367 \pm 0.459$ & $1.111 \pm 0.088$ & $1.299 \pm 0.247$ \\
\hline \multirow{2}{*}{$\mathbf{P 2 - V}$} & $25^{\circ} \mathrm{C}$ & $0.312 \pm 0.007$ & $0.337 \pm 0.010$ & $0.558 \pm 0.005$ & $1.011 \pm 0.015$ & $1.021 \pm 0.032$ \\
\cline { 2 - 7 } & $32^{\circ} \mathrm{C}$ & $8.213 \pm 0.839$ & $6.863 \pm 0.660$ & $5.600 \pm 1.024$ & $1.085 \pm 0.243$ & $0.990 \pm 0.036$ \\
\hline \multirow{2}{*}{$\mathbf{P 3}$} & $25^{\circ} \mathrm{C}$ & $52.476 \pm 4.793$ & $95.827 \pm 10.097$ & $91.426 \pm 7.964$ & $0.971 \pm 0.045$ & $1.271 \pm 0.177$ \\
\cline { 2 - 7 } & $32^{\circ} \mathrm{C}$ & $62.471 \pm 2.984$ & $132.936 \pm 9.109$ & $121.771 \pm 6.999$ & $1.027 \pm 0.049$ & $1.181 \pm 0.056$ \\
\hline \multirow{2}{*}{$\mathbf{P 3 - V}$} & $25^{\circ} \mathrm{C}$ & $39.301 \pm 2.757$ & $66.951 \pm 7.110$ & $60.291 \pm 5.153$ & $0.941 \pm 0.107$ & $1.252 \pm 0.116$ \\
\cline { 2 - 7 } & $32^{\circ} \mathrm{C}$ & $79.018 \pm 0.714$ & $103.778 \pm 4.057$ & $79.218 \pm 6.072$ & $1.154 \pm 0.059$ & $1.062 \pm 0.165$ \\
\hline
\end{tabular}




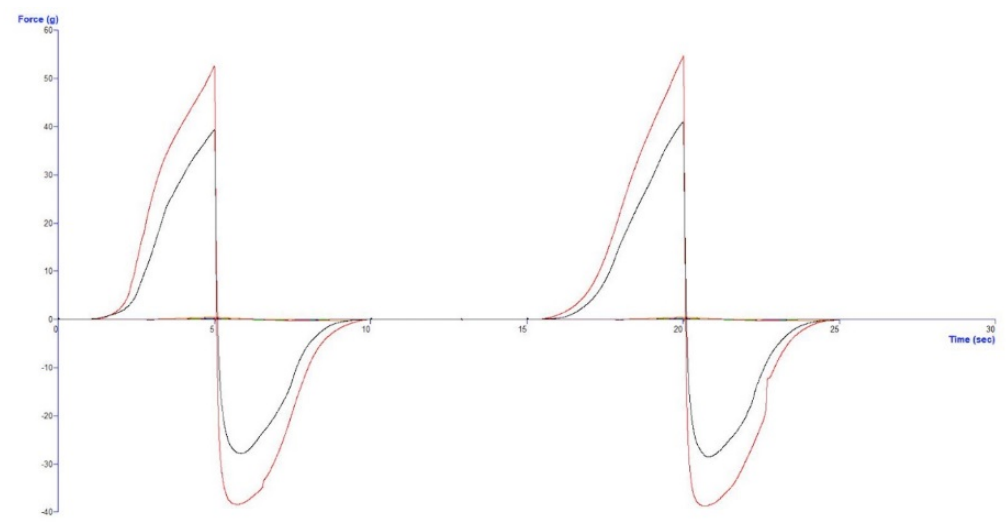

Figure 1. Force-time curves of the gel formulations at $25^{\circ} \mathrm{C}$ (Blue line: P1, Yellow line: P1V, Green line: P2, Purple line: P2V, Red line: P3, Black line: P3V)

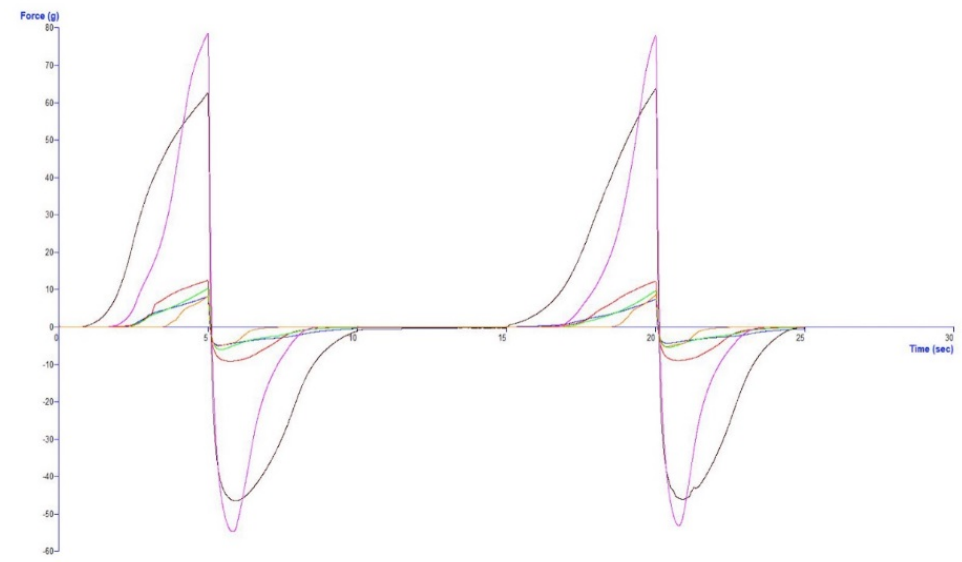

Figure 2. Force-time curves of the gel formulations at $32^{\circ} \mathrm{C}$ (Blue line: P1, Red line: P1V, Green line: P2, Yellow line: P2V, Brown line: P3, Purple line: P3V)

Adhesiveness value defines the work required to detach the probe from the formulation and it can be related to adhesive properties. Higher adhesiveness value indicates greater adhesion at the tissue surface and it is a desired characteristic to increase the drug retention time. Based on the results it can be seen that, highest adhesiveness value was obtained with P3 formulations, which also shows high gel strength properties. Also in all of the formulations, the increased temperature caused higher adhesive properties.

Cohesiveness shows the effect of repeated shearing stresses on the formulations. Elasticity represents the return rate of the deformed sample to its beginning condition. Lower numerical value in the elasticity indicates greater product elasticity. As it can be seen from Table 4; cohesiveness and elasticity values are nearly 1 as expected and they did not significantly change with the addition of VRC or increasing temperature $(\mathrm{P}>0.05)$. 


\section{Rheological Measurements}

The evaluation of rheological properties for in situ gels is one of the most important parameters for predicting their in vivo behavior. The rheological properties especially affect both ease of application and retention within the application area. Therefore; P2-V formulation, which showed gelling temperature at $32^{\circ} \mathrm{C}$, was selected and evaluated for its rheological behavior. The rheological properties were determined both at room temperature $\left(25^{\circ} \mathrm{C}\right)$ and at eye temperature $\left(32^{\circ} \mathrm{C}\right)$ to observe the changes in the gel structure.

First of all, the shear stress changes upon shear rates have been observed to determine whether the rheological behavior of the formulation is Newtonian or non-Newtonian. Obtained results showed that in continuous shear rheometry, P2-V formulation showed a non-Newtonian pseudo-plastic flow, showing decreasing viscosity with progressive increases in the shear rate both at $25^{\circ} \mathrm{C}$ and $32^{\circ} \mathrm{C}$ (Figure 3). In accordance with this results, it was previously reported in the literature that at temperatures especially higher than the sol-gel transition temperature, non-Newtonian flow is typical for poloxamer solutions $[29,30]$. Also, it can be seen that higher viscosity and shear stress values were obtained at higher temperature values which indicates the temperature-dependent gellation. This result is also compatible with the results of mechanical analysis where significantly higher hardness values are observed at higher temperature values.

Furthermore; P2-V formulation was subjected to a sinusoidal shear stress and oscillatory rheology studies were performed. In this way, both elastic-like and viscous-like properties were determined. The structural and dynamical properties were elucidated and two dynamic modui were obtained: 1) the storage modulus ( $\mathrm{G}^{\prime}$, a measure of the elasticity); and 2$)$ the loss modulus $\left(\mathrm{G}^{\prime \prime}\right.$, representing viscous components at given frequency).

It was stated in the literature that a strong gel should exhibit a solid-like mechanical spectrum and the storage modulus should be higher than the loss modulus $\left(\mathrm{G}^{\prime}>\mathrm{G}^{\prime \prime}\right)$ [31]. Figure 4 shows the plots of $\mathrm{G}^{\prime}$ and $\mathrm{G}^{\prime \prime}$ as a function of frequency at two different temperature values. It can be seen that, at both temperature values, $G^{\prime}$ dominated $G^{\prime \prime}$ for all frequency ranges, which indicates a strong gel structure. The gap between the two moduli is wider at $32^{\circ} \mathrm{C}$ indicating stronger gel strength $\left(G^{\prime}>>G^{\prime \prime}\right)$ [32].

The loss tangent is the value of phase angle $\left(\tan \delta=\mathrm{G}^{\prime} / \mathrm{G}^{\prime \prime}\right)$ and it is a measure of the relative contribution of viscous components to the mechanical properties of the materials. As it can be seen from Figure 4 , it was $<1$ both at $25^{\circ} \mathrm{C}$ and $32^{\circ} \mathrm{C}$ which shows solid gel response. As $\tan \delta$ becomes smaller, the elasticity of the formulation increases, while the viscous behavior is reduced. As expected, $\tan \delta$ value of P2-V was found to be higher at $25^{\circ} \mathrm{C}$ than $32^{\circ} \mathrm{C}$ which indicates that the formulation showed more elastic property at higher temperature value and this result is in accordance with the results of oscillatory measurements [33]. 
Dynamic viscosity $\left(\eta^{\prime}\right)$ is described as the flow resistance of the formulation in the structure state to oscillating movement. The higher dynamic viscosity value means the greater the resistance to flow. In our study, $\eta^{\prime}$ value was found to be significantly higher as the temperature increases and it indicates more consistent gel structure. This result is also in accordance with other mechanical and rheological studies.

\section{In vitro drug release studies}

In vitro drug release of $\mathrm{P} 1-\mathrm{V}, \mathrm{P} 2-\mathrm{V}$ and $\mathrm{P} 3-\mathrm{V}$ formulations was evaluated by dialysis bag method and the results were given at Figure 5. The results showed that the Poloxamer type or ratio did not significantly affect the release rate of VRC from the in situ gel formulations. In all of the formulations, sustained drug releases were obtained up to 24 hours.

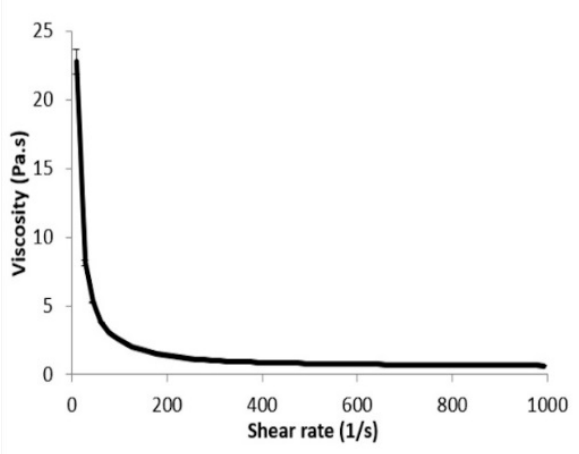

$25^{\circ} \mathrm{C}$

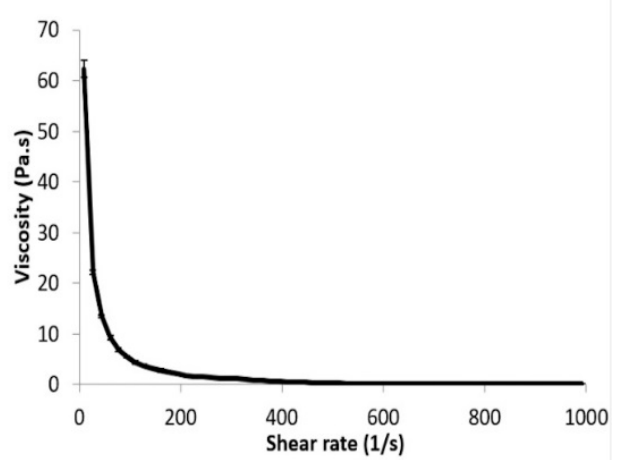

$32^{\circ} \mathrm{C}$

Figure 3. Viscosity versus shear rate graphs of the formulations 
J. Fac. Pharm. Ankara, 44(1): 33-49, 2020

Ustundag Okur et al.

45
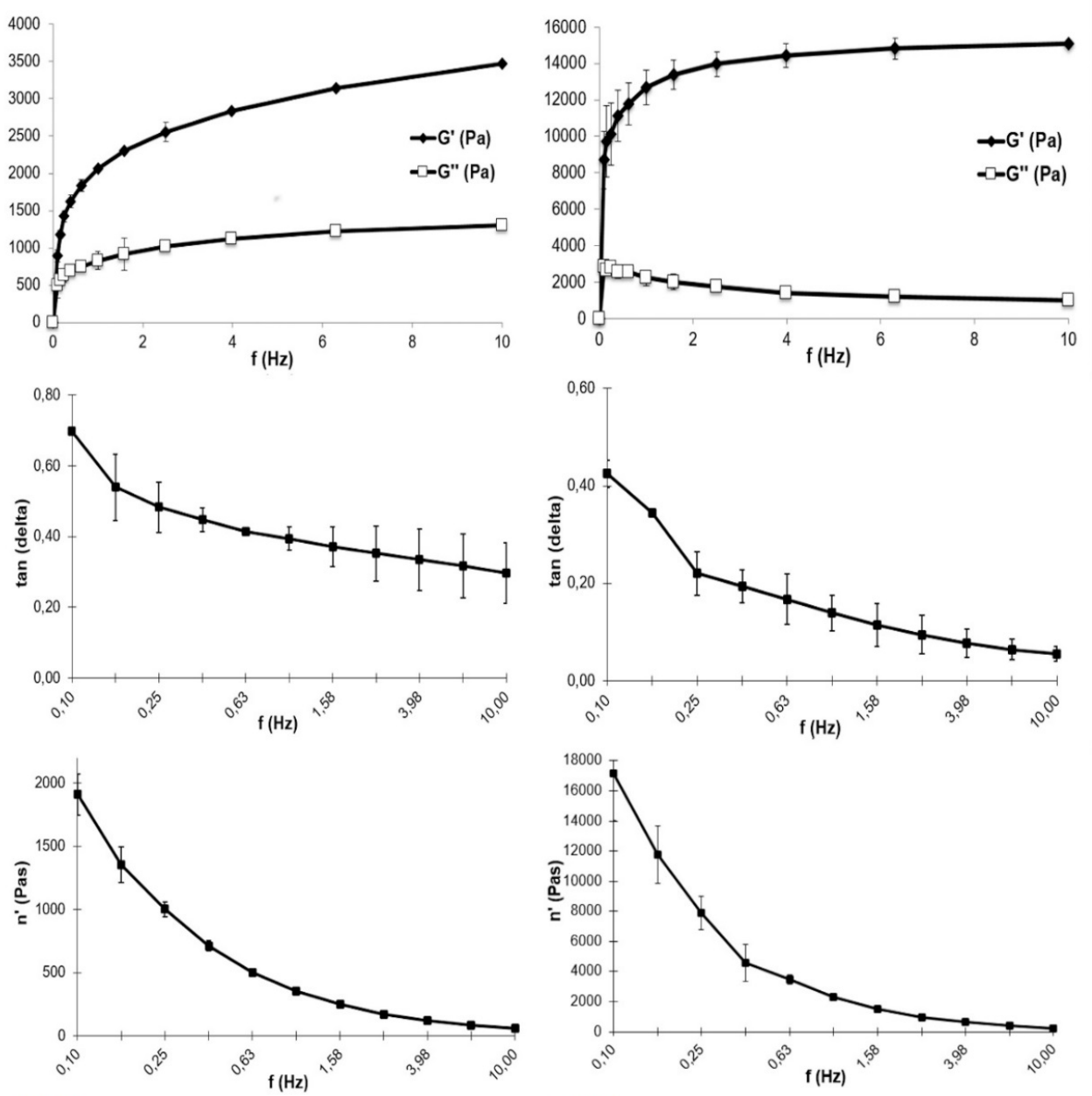

$25^{\circ} \mathrm{C}$

$32^{\circ} \mathrm{C}$

Figure 4. Frequency-dependent changes of viscoelastic properties of P2-V formulation

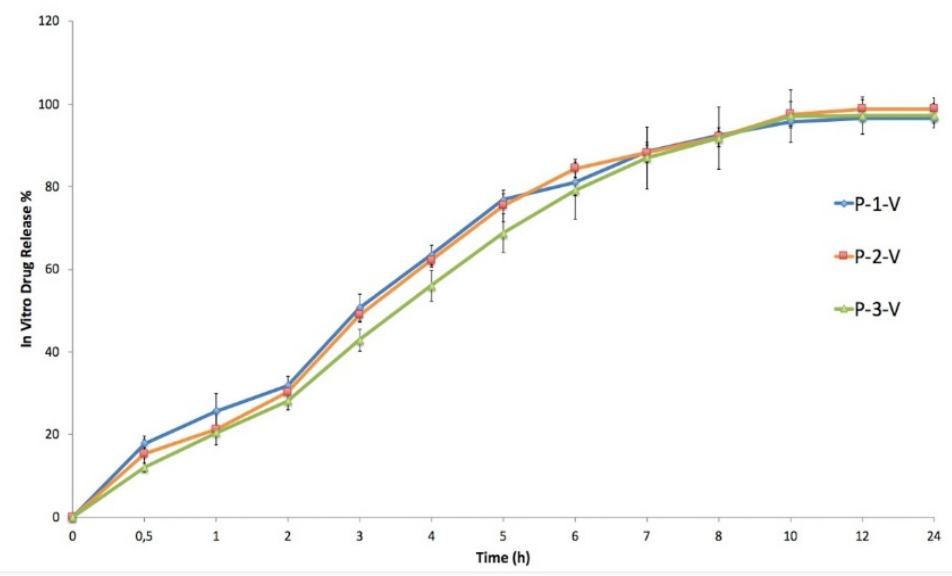

Figure 5. In vito drug release results of VCZ loaded in situ gels (n:3, \pm STD) 


\section{Stability}

According to the detailed characterization studies, the optimized VCZ loaded in situ gel P2-V was chosen as optimum formulation and was subjected to stability study for three months at $4 \pm 1{ }^{\circ} \mathrm{C}$ in the refrigerator and $25 \pm 1^{\circ} \mathrm{C}$ (relative humidity $60 \%$ ). Based on research, testing of stability aimed to know the time of storage and the use of a material. The stability study revealed no significant change in visual appearance, clarity, $\mathrm{pH}$, gelling capacity and drug content of the formulation (Table 4). Thus, in can be concluded that VCZ in situ gel formulated with 20\% (w/w) P 407 and 8\% (w/w) P 188 was successfully formulated for ocular administration.

Table 4. Stability studies results of VCZ loaded formulations (P2-V)

\begin{tabular}{llll}
\hline Parameters & $\mathbf{t}=\mathbf{0}$ & $\mathbf{t}=\mathbf{3}$ & \\
& $\mathbf{4}$ and $\mathbf{2 5}{ }^{\circ} \mathbf{C}$ & $\mathbf{4}^{\mathbf{}} \mathbf{C}$ & $\mathbf{2 5}{ }^{\circ} \mathbf{C}$ \\
\hline pH & $6.357 \pm 0.006$ & $6.697 \pm 0.006$ & $6.987 \pm 0.006$ \\
Drug content (\%) & $92.6255 \pm 0.609$ & $92.487 \pm 1.844$ & $92.657 \pm 0.276$ \\
\hline
\end{tabular}

The generally poor bioavailability of ophthalmic formulations can be improved by new formulations with a prolonged residence time. In this study, the potential of VCZ loaded thermosensitive in situ gels as drug carriers for ocular delivery was evaluated. The optimized VCZ loaded in situ gel formulation obtained from this study was composed of 20\% (w/w) P 407 and 8\% (w/w) P 188 as the gelling matrix. This will ensure that the patient could be treated at much longer time points, meaning that patients could be treated as outpatients, reducing hospital admissions.

\section{DECLARATION OF INTEREST}

The authors declare no conflict of interest.

\section{ACKNOWLEDGEMENTS}

The authors would like to thank to the BASF for providing the poloxamers.

\section{REFERENCES}

1. Bachu, R.D., Chowdhury, P., Al-Saedi, Z.H.F., Karla, P.K., and Boddu, S.H.S. (2018) Ocular Drug Delivery Barriers-Role of Nanocarriers in the Treatment of Anterior Segment Ocular Diseases. Pharmaceutics, 10. Accessed 10 April 2019.

2. Bucolo, C., Drago, F., and Salomone, S. (2012) Ocular drug delivery: a clue from nanotechnology. Front. Pharmacol., 3,188. Accessed 10 April 2019. 
3. Application of Nanotechnology in Ocular Drug Delivery (2013). In: Yang X, Patel A, Dutt Vadlapudi A, K. Mitra A, editors. Treatise on Ocular Drug Delivery. BENTHAM SCIENCE PUBLISHERS. pp. 253-284. Accessed 10 April 2019.

4. Leeming, J., Diamond, J.P., White, L., Leeming, J.P., Hoh, H.B., and Easty, D.L. (1995) Ciprofloxacin in treatment of bacterial keratitis: A new method for comparative evaluation of ocular drug penetration ofloxacin in treatment of bacterial keratitis: a new method for comparative evaluation of ocular drug penetration,606-609. doi:10.1136/bjo.79.6.606.

5. Üstündağ-Okur, N., Yoltas, A., and Yozgatli, V. (2016) Development and Characterization of Voriconazole Loaded In Situ Gel Formulations for Ophthalmic Application. Turk J Pharm Sci, 13,311-317. doi:10.4274/tjps.2016.05.

6. Kumar, R. and Sinha, V.R. (2014) Colloids and Surfaces B : Biointerfaces Preparation and optimization of voriconazole microemulsion for ocular delivery. Colloids Surfaces $B$ Biointerfaces, 117,82-88. doi:10.1016/j.colsurfb.2014.02.007.

7. Üstündağ Okur, N., Çağlar, E.Ş., and Yozgatli, V. (2016) Development and Validation of an Hplc Method for Voriconazole Active Substance in Bulk and its Pharmaceutical Formulation. MARMARA Pharm. J., 20,79. doi:10.12991/mpj.20162076793.

8. Darwhekar, G., Jain, P., Jain, D.K., and Agrawal, G. (2011) Development and Optimization of Dorzolamide Hydrochloride and Timolol Maleate in Situ Gel for Glaucoma Treatment INTRODUCTION : Asian J. Pharm Ana, 1,93-97.

9. Üstündağ Okur, N., Yozgatlı, V., Okur, M.E., Yoltaş, A., and Siafaka, P.I. (2019) Improving therapeutic efficacy of voriconazole against fungal keratitis: Thermo-sensitive in situ gels as ophthalmic drug carriers. J. Drug Deliv. Sci. Technol.,. doi:10.1016/j.jddst.2018.12.005.

10. Choi, H.-G., Oh, Y.-K., and Kim, C.-K. (1998) In situ gelling and mucoadhesive liquid suppository containing acetaminophen: enhanced bioavailability. Int. J. Pharm., 165,23-32. Accessed 30 June 2019.

11. Okur, M.E., Ayla, Ş., Batur, Ş., Yoltaş, A., Genç, E., Pertek, S., and Üstündağ Okur, N. (2019) Evaluation of In Situ Gel Containing Pycnogenol for Cutaneous Wound Healing. Medeni. Med. $J$., doi:10.5222/mmj.2019.29053.

12. Aksu, N.B., Yozgatl1, V., Okur, M.E., Ayla, Ş., Yoltaş, A., and Üstündağ Okur, N. (2019) Preparation and evaluation of QbD based fusidic acid loaded in situ gel formulations for burn wound treatment. J. Drug Deliv. Sci. Technol., 52,110-121. doi:10.1016/j.jddst.2019.04.015.

13. Jones, D.S., Woolfson, A.D., and Djokic, J. (2002) Texture profile analysis of bioadhesive polymeric semisolids: Mechanical characterization and investigation of interactions between formulation components. J. Appl. Polym. Sci., 61,2229-2234. doi:10.1002/(sici)10974628(19960919)61:12<2229::aid-app24>3.3.co;2-8.

14. Jones, D., Woolfson, D., and Brown, A.F. (1997) International journal of pharmaceutics. Int. J. Pharm., 151,223-233. Accessed 1 July 2019.

15. Andrews, G.P., Gorman, S.P., and Jones, D.S. (2005) Rheological characterisation of primary and binary interactive bioadhesive gels composed of cellulose derivatives designed as ophthalmic viscosurgical devices. Biomaterials, 26,571-580. Accessed 1 July 2019. 
16. Baloglu, E., Karavana, S.Y., Senyigit, Z.A., and Guneri, T. (2011) Rheological and mechanical properties of poloxamer mixtures as a mucoadhesive gel base. Pharm. Dev. Technol., 16,627636. Accessed 1 July 2019.

17. Üstündağ-Okur, N., Gökçe, E.H., Bozbiyik, D.I., Eğrilmez, S., Özer, Ö., and Ertan, G. (2014) Preparation and in vitro-in vivo evaluation of ofloxacin loaded ophthalmic nano structured lipid carriers modified with chitosan oligosaccharide lactate for the treatment of bacterial keratitis. Eur. J. Pharm. Sci., 63,204-215. doi:10.1016/j.ejps.2014.07.013.

18. Andrews, G.P. and Jones*, D.S. (2006) Rheological Characterization of Bioadhesive Binary Polymeric Systems Designed as Platforms for Drug Delivery Implants. Biomacromolecules, 7,899-906. Accessed 30 June 2019.

19. Destruel, P.-L., Zeng, N., Maury, M., Mignet, N., and Boudy, V. (2017) In vitro and in vivo evaluation of in situ gelling systems for sustained topical ophthalmic delivery: state of the art and beyond. Drug Discov. Today, 22,638-651. Accessed 26 May 2019.

20. Devi, D.R., Sandhya, P., and Hari, B.N.V. (2013) Poloxamer: A novel functional molecule for drug delivery and gene therapy. J. Pharm. Sci. Res., 5,159-165.

21. Ayla, S., Okur, M.E., Günal, M.Y., Özdemir, E.M., Çiçek Polat, D., Yoltaş, A., Biçeroğlu, Ö., and Karahüseyinoğlu, S. (2019) Wound healing effects of methanol extract of Laurocerasus officinalis roem. Biotech. Histochem., 94,180-188.

22. Üstündă̆ Okur, N., Filippousi, M., Okur, M.E., Ayla, Ş., Çağlar, E.Ş., Yoltaş, A., and Siafaka, P.I. (2018) A novel approach for skin infections: Controlled release topical mats of poly(lactic acid)/poly(ethylene succinate) blends containing Voriconazole. J. Drug Deliv. Sci. Technol., 46,74-86.

23. Efron, N., Young, G., and Brennan, N.A. (1989) Ocular surface temperature. Curr. Eye Res., $8,901-906$.

24. Gade, S., Patel, K.K., Gupta, C., Anjum, M.M., Deepika, D., Agrawal, A.K., and Singh, S. (2019) An Ex Vivo Evaluation of Moxifloxacin Nanostructured Lipid Carrier Enriched In Situ Gel for Transcorneal Permeation on Goat Cornea. J. Pharm. Sci.,. Accessed 26 May 2019.

25. Makwana, S.B., Patel, V.A., and Parmar, S.J. (2016) Development and characterization of in-situ gel for ophthalmic formulation containing ciprofloxacin hydrochloride. Results Pharma Sci., 6,16.

26. He, Z., Wang, Z., Zhang, H., Pan, X., Su, W., Liang, D., and Wu, C. (2011) Doxycycline and hydroxypropyl- $\beta$-cyclodextrin complex in poloxamer thermal sensitive hydrogel for ophthalmic delivery. Acta Pharm. Sin. B, 1,254-260.

27. Okur, M.E., Ayla, Ş., Çiçek Polat, D., Günal, M.Y., Yoltaş, A., and Biçeroğlu, Ö. (2018) Novel insight into wound healing properties of methanol extract of Capparis ovata Desf. var. palaestina Zohary fruits. J. Pharm. Pharmacol., 70,1401-1413.

28. Üstündağ Okur, N., Hökenek, N., Okur, M.E., Ayla, Ş., Yoltaş, A., Siafaka, P.I., and Cevher, E. (2019) An alternative approach to wound healing field; new composite films from natural polymers for mupirocin dermal delivery. Saudi Pharm. J., 27,738-752. doi:10.1016/j.jsps.2019.04.010. 
29. Freitas, M.N., Farah, M., Bretas, R.E.S., Ricci-Júnior, ; E., and Marchetti, J.M. (2006) Rheological characterization of Poloxamer 407 nimesulide gels. J. Basic Appl. Pharm. Sci., 27,113-118.

30. Ay Şenyiğit, Z., Karavana, S.Y., Ilem Ozdemir, D., Caliskan, C., Waldner, C., Sen, S., BernkopSchnürch, A., and Baloglu, E. (2015) Design and evaluation of an intravesical delivery system for superficial bladder cancer: preparation of gemcitabine HCl-loaded chitosan\&amp;ndash;thioglycolic acid nanoparticles and comparison of chitosan/poloxamer gels as carriers. Int. J. Nanomedicine, 10,6493.

31. Dumortier, G., Grossiord, J.L., Zuber, M., Couarraze, G., and Chaumeil, J.C. (1991) Rheological study of a thermoreversible morphine gel. Drug Dev. Ind. Pharm., 17,1255-1265.

32. M.A. Fathalla, Z., Vangala, A., Longman, M., Khaled, K.A., Hussein, A.K., El-Garhy, O.H., and Alany, R.G. (2017) Poloxamer-based thermoresponsive ketorolac tromethamine in situ gel preparations: Design, characterisation, toxicity and transcorneal permeation studies. Eur. J. Pharm. Biopharm., 114,119-134.

33. Baloglu, E., Karavana, S.Y., Senyigit, Z.A., Hilmioglu-Polat, S., Metin, D.Y., Zekioglu, O., Guneri, T., and Jones, D.S. (2011) In-situ gel formulations of econazole nitrate: preparation and in-vitro and in-vivo evaluation. J. Pharm. Pharmacol., 63,1274-1282. Accessed 1 July 2019. 